\title{
A Semi-Systematic Review of Capillary Irrigation: The Benefits, Limitations, and Opportunities
}

\author{
Niranjani P. K. Semananda *, James D. Ward and Baden R. Myers \\ Natural and Built Environments Research Centre, School of Natural and Built Environments, \\ University of South Australia, Mawson Lakes 5095, Australia; james.ward@unisa.edu.au (J.D.W.); \\ baden.myers@unisa.edu.au (B.R.M.) \\ * Correspondence: niranjani.semananda@mymail.unisa.edu.au; Tel.: +61-8-8302-3000
}

Received: 19 July 2018; Accepted: 28 August 2018; Published: 1 September 2018

\begin{abstract}
Capillary irrigation systems have been investigated for some years as a means to deliver water to plants in container gardening. This review paper identifies that traditional capillary irrigation systems such as capillary wicks, capillary mats, and ebb and flow systems have been shown to produce higher crop yields and use less water than conventional irrigation methods. In addition, capillary irrigation offers an added advantage by reducing the volume of potentially harmful leachate into surrounding soil environments. However, these systems are basically limited to small pot sizes and are widely used for growing ornamental and nursery plants in glasshouse conditions. Further, the cost and complexity of Negative Pressure Difference Irrigation may have limited its practical use. Conversely, wicking beds (WBs) are low-tech and water-efficient systems which can be used for growing plants with different rooting depths. Irrespective of the wide acceptance of WBs among the growing community, this review recognises that there is no published research providing design recommendations for WBs and their expected performance relative to other irrigation systems. Therefore, some potential advantages of WBs are noted in the context of capillary irrigation research; however, a substantial knowledge gap exists relating to the optimised design and use of WBs.
\end{abstract}

Keywords: capillary irrigation; PRISMA; review; subirrigation; water use efficiency; wicking bed

PACS: J0101

\section{Introduction}

Capillary irrigation is a form of subirrigation which uses the capillary action of a medium to deliver water to a plant from a water source at or below the base of the growing bed. Container-based subirrigated systems such as capillary mats, ebb and flow systems, capillary wicks, and subirrigated planters (SIPs) are all irrigation systems that depend on capillary action. These systems have been widely recommended in literature and guideline documents [1,2] as they can grow healthy plants and flowers while reducing environmental impact, water demand, and irrigation effort.

Ferrarezi et al. [3] showed that capillary-based subirrigation systems have been widely applied in controlled environments for the growth of ornamental plants, and more recently for vegetables and fruit tree seedlings. Closed-cycle capillary irrigation is a promising technology for growing crops with minimal environmental impact; however, application of capillary-based subirrigation systems in small-scale commercial agriculture for growing fruits and vegetables in outdoor conditions has been limited [3]. The main focus of this review was therefore to identify: (i) the most common capillary irrigation systems; (ii) the performance of capillary irrigation systems in relation to other best-practice irrigation systems; and (iii) the documented benefits, limitations, and opportunities in capillary irrigation for future use and research. 


\section{Review Method}

A qualitative analysis of peer-reviewed papers on capillary irrigation was implemented using a new systematic review guideline, namely, the Preferred Reporting Items for Systematic Review and Meta-Analysis (PRISMA) approach. A systematic review process is a rigorous method which guides a reviewer on selection of published studies in an unbiased manner, and presents an alternative to traditional reviews [4]. Further, a traditional review is often restricted to literature already known to review authors or to literature identified using a basic search which can introduce bias. The PRISMA method has been widely used in medical sciences, and is a potentially useful tool in the field of horticulture research. The current study demonstrates, for the first time, the application of this systematic review approach to scientific literature related to capillary irrigation systems.

This review was based on searching the total available record of research in two multidisciplinary abstract databases up to August 2018, namely, Scopus (since 1960) and Web of Science (since 1975), to collect peer-reviewed articles. Boolean operators were used in each database to connect the primary keyword "capillary irrigation" and its synonyms to the subsequent keyword "container" and its synonyms as detailed in Table 1.

Table 1. Article screening criteria and synonyms.

\begin{tabular}{cl}
\hline Criterion & \multicolumn{1}{c}{ Synonyms } \\
\hline Capillary Irrigation & $\begin{array}{l}\text { "capillary irrigation" or "capillary wick" or "capillary mat" or "wicking bed *" or "sub } \\
\text { irrigation" or "sub-irrigated planter *" or "subirrigated planter *" or "self-watering" }\end{array}$ \\
\hline Container & Container * or pot * or bucket * or tub * or drum * or barrel * \\
\hline
\end{tabular}

The asterisk * truncation symbol was used to find both single and plural forms of a word. Inclusions and exclusions were carefully defined and a systematic search was carried out within the peer-reviewed literature. Potentially relevant articles were collected and qualitatively evaluated using the inclusion and exclusion criteria detailed below.

\section{Systematic Review}

The search was first narrowed by selecting articles within the subject area of agriculture, environmental engineering, horticulture, plant science, environmental science, or any other related area of plant physiology. Articles not in the English language were excluded.

Relevant articles were then selected based on four main criteria: (i) the study must have used one or more irrigation systems that were related to capillary or subirrigated irrigation techniques; (ii) the plant must have been grown in a container, confined area, or closed system; (iii) the experimental crop used must have been an ornamental or fruit/vegetable crop; (iv) the study must have evaluated the performance of the irrigation system(s), for example, in terms of yield, environmental impact, water use, water saving or water use efficiency, and/or labour.

The screening of articles was carried out manually in three stages: (i) title; (ii) abstract; and (iii) full text screen of potentially relevant studies.

\section{Literature Review}

In total, 200 published papers (91 from Scopus and 109 from Web of Science) were potentially relevant to this review prior to the title and abstract screening process (Figure 1). Following the inclusion criteria (1 to 4) as outlined in Section 2, 43 and 91 articles were removed after title and abstract screening, respectively, as they were judged to be irrelevant or replicated in both databases. This process yielded 66 studies for full text review, out of which 46 met the inclusion criteria 1 to 4 of this study. Of the 13 excluded due to lack of full text availability, 10 were from conference proceedings.

Of the 48 final selected studies, just over $90 \%$ were conducted in a greenhouse or in a controlled environment, and about two-thirds reported on the growth of ornamental crops (Figure 2). 
Figure 3 summarises the classification of studies investigating capillary irrigation performance, accumulation of salt by means of electrical conductivity (EC), and environmental impact, including the number in (and overlapping between) each category. Of the 48 studies, $96 \%$ reported on the performance of the capillary irrigation system, such as by assessing yield/water efficiency, environmental impact, and EC. Environmental impacts (such as nutrient discharge) were reported in about one-third of studies, almost all of which also discussed performance more generally. A similar relationship was found with studies that specifically addressed salt accumulation or EC, usually also along with performance.

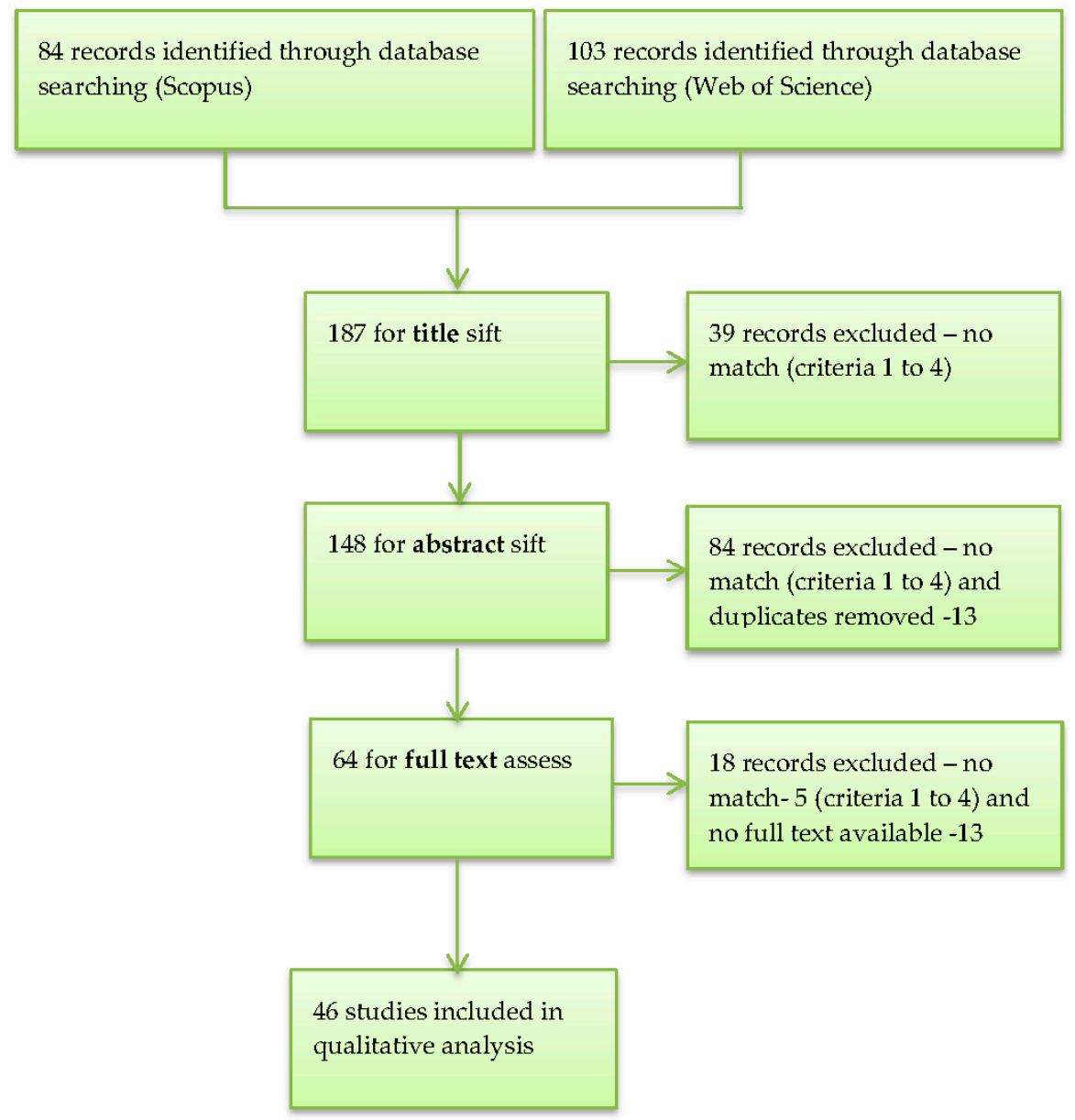

Figure 1. Flow chart for selection of articles for systematic review [5].
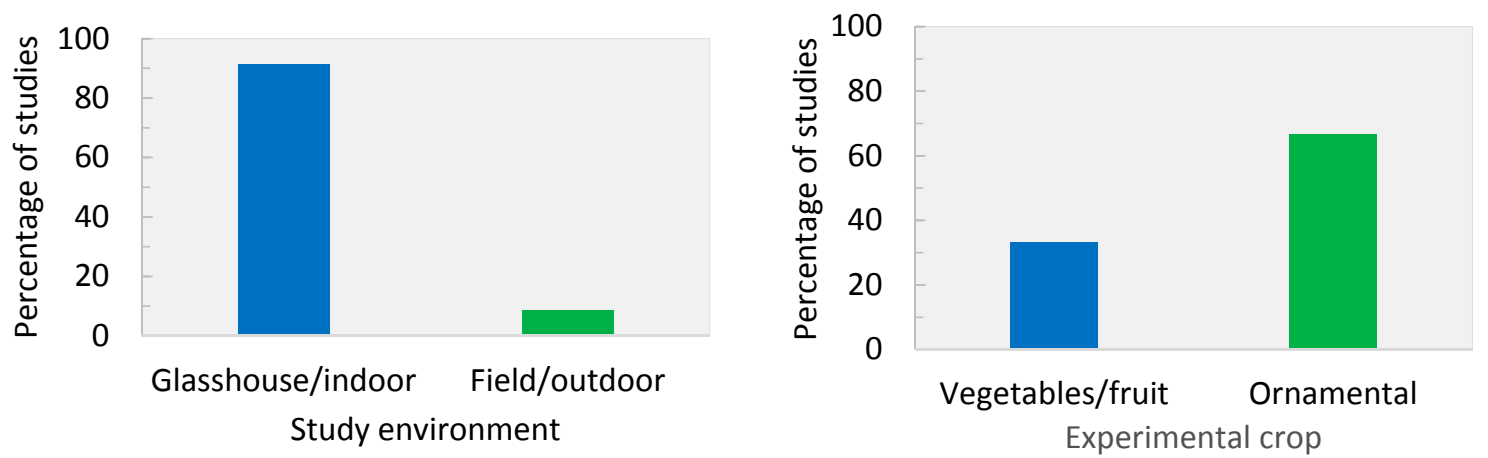

Figure 2. Distribution of studies based on the study environment (left) and experimental crop (right). 


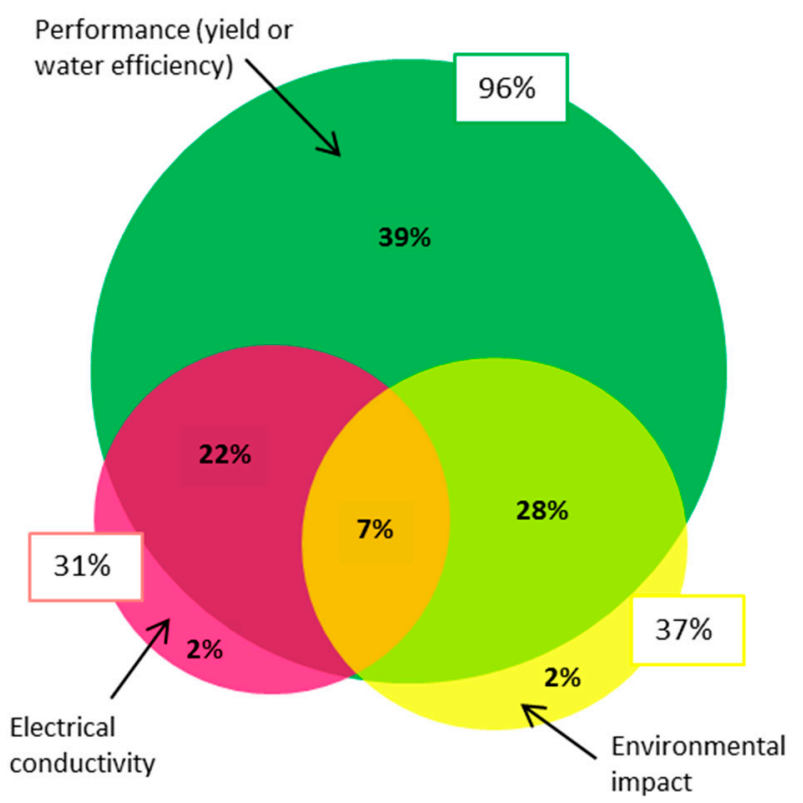

Figure 3. Percentage of studies reporting the performance, electrical conductivity (EC) of irrigation water, and environmental impact of capillary irrigation systems.

\subsection{Capillary Irrigation Systems}

A majority of the studies compared subirrigation systems (such as ebb and flow, capillary wick, or capillary mat) with a top watering irrigation technique such as overhead sprinklers, or hand or drip irrigation. Widely used substrate media for growing plants in these systems included peat, perlite, bark, rock wool, compost, or recycled organic materials (or a mixture of those). We did not find any scientific research focusing on wicking bed (WB) irrigation systems as currently applied in garden horticulture; in light of this, the importance of evaluating the effectiveness of a WB is discussed further in this review.

Ebb and flow is a widely used irrigation system which includes a watertight bench where plants are grown, a reservoir, and a pump. They come in two designs-flooded bench systems (Figure 4d) and trough systems (Figure 4e). For the flooded bench, a nutrient solution is pumped to the watertight bench/table once or twice a week, or up to several times a day if necessary, depending on weather and plant water requirements [6]. The solution is then allowed to remain at the bench level for approximately 10 to $30 \mathrm{~min}$ or until soil is saturated before draining back to the storage tank located below the benches. In a "trough system", plants are placed on several parallel troughs directly on the greenhouse benches. The troughs are inclined on the benches and water is delivered to the upper end. Water flows under gravity and any not intercepted by plants is then collected at the lower end [7]. 


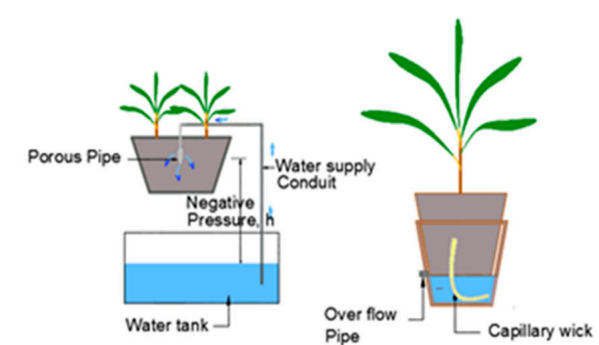

(a)

(b)

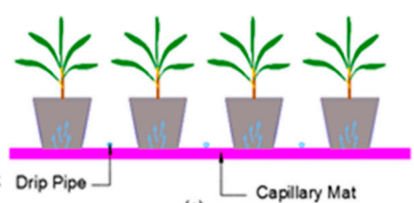

(c)

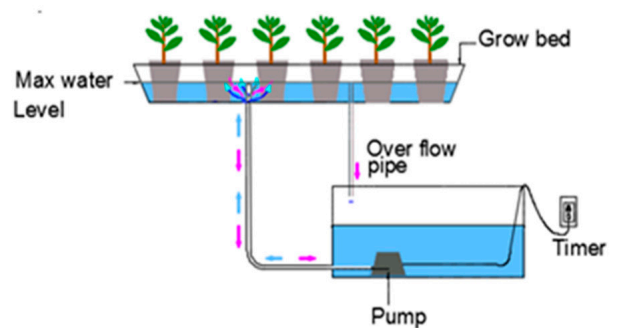

(d)

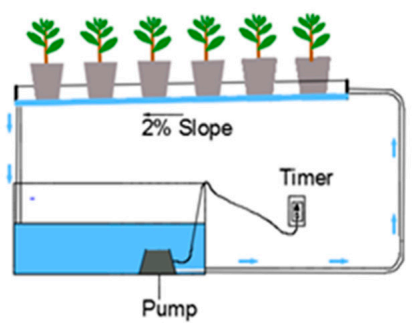

(e)

Figure 4. Capillary irrigation systems: (a) negative pressure difference irrigation (NPDI), (b) capillary wick, (c) capillary mat, (d) ebb and flow-flood benches, (e) ebb and flow-trough.

Wicking bed systems are not a new technology, but a new approach to irrigation that is based on plant water uptake and evapotranspiration rate (Figure 5). While several studies have illustrated that capillary irrigation systems such as capillary wicks, capillary mats, and ebb and flow systems need less water than conventional irrigation methods, all systems come with disadvantages that render them unsuitable for urban agriculture. Wicking bed systems are growing in popularity. However, despite their popularity, they did not appear at all in the literature search for this review.

In contrast to traditional capillary wick systems, the WB system has a media-filled reservoir beneath the unsaturated soil (root zone). The two layers are separated by a geotextile fabric (Figure 5). A WB functions similarly to a capillary wick system, except that instead of water being delivered via a narrow wick material, it is able to move upward through the entire soil area in contact with the reservoir, due to capillary suction from the soil in WBs. As such, the limitations in terms of pot size are not expected to apply to WBs.

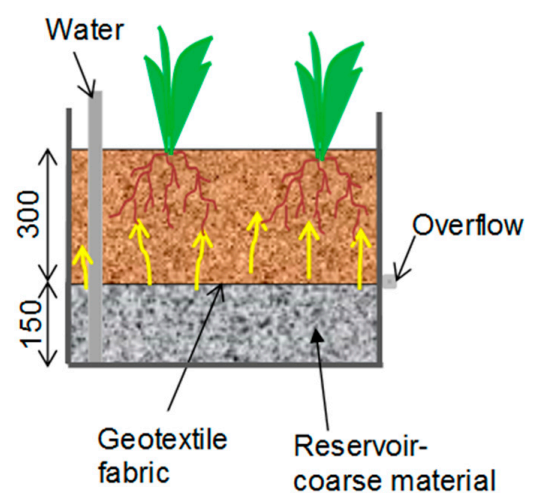

Figure 5. Systematic diagram of a wicking bed.

A coarse material is typically selected for the reservoir, due to its high void content and permeability for rapid filling (a practical consideration), and low resistance to water being drawn out by suction (when the reservoir is depleted) from the overlying layers [8]. In WBs, water is delivered by capillary action to the root zone in response to the water requirements of the plant, allowing individual 
plants to uptake water according to their own transpiration rate. Thus, the behaviour should be similar to that of the capillary wick system, but on a larger scale.

In principle, in a WB, each plant should get precisely the right amount of water at a particular time, making the system a possible solution for water-efficient irrigation, particularly in urban environments such as households and community gardens. Indeed, WBs are gaining popularity among the gardening community because they are very simple to construct, require no precise controls for operation, and are scalable. Informal recommendations abound as to their construction details. Our review of grey literature revealed widespread claims that WBs can save up to $90 \%$ of water compared with traditional surface irrigation [9], with no evidence provided to support the claim. While recent research [10] on a subirrigated planter design (akin to, though not labelled, a WB) indicated that this approach may have higher yield and lower maintenance than other container gardening systems, it did not explicitly investigate the water use or labour efficiency, and recommended further research into these areas. However, despite increasing enthusiasm for, and claims about, WB performance, our literature review did not identify any comprehensive studies to investigate the performance of these systems in terms of crop growth, water use efficiency (WUE), environmental impact, or labour needs. To the authors' knowledge, the only published scientific study relating to WBs is our own previous paper [11].

WBs appear to offer an irrigation solution that carries all of the advantages of the various capillary and subirrigation techniques reviewed in this study (no runoff, low evaporation, responsive to plant water demand) with few if any of their disadvantages (high cost, need for precision control, limited container size). However, salt accumulation at the soil surface is common in WB systems. Due to the lack of research on WBs, we contend that there is a specific - and very important-knowledge gap relating to the verification of performance, and of design guidance, of WBs.

Our extensive literature search was unable to find published research that supports any of the widespread design recommendations for WB dimensions, effectiveness, or water efficiency. It has long been understood that the capillary rise of water in soil reaches a maximum height (dependent on the medium), with moisture content decreasing with distance above the saturated water level $[12,13]$. It follows, therefore, that in a WB, the soil properties and the reservoir and soil bed depths should be the main parameters that will drive ultimate plant performance and water efficiency in the system. These interrelated factors should be the focus of continued research.

It should be noted that there are technologies available that use similar principles to wicking beds. For example, the ANOVApot ${ }^{\circledR}$ is a newly patented container that has been developed for growth of ornamental plants in the nursery industry. One of the main features of the ANOVApot ${ }^{\circledR}$ is the mesh-covered central hole in the base which helps to control root escape [14]. The origin and the development of the ANOVApot ${ }^{\circledR}$ was described by Hunter and Scattini [15]. In a unique application, Hunter et al. [16] used the ANOVApot ${ }^{\circledR}$ with a constant water table arrangement to measure plant root weights without physical recovery.

Capillary mats are widely used for growing containerised nursery plants. Capillary mats are absorbent materials that are usually made of synthetic fibrous material, such as carpet underlay or geotextile fabric [1], on which containers are placed (Figure 4c). Mats are continuously wetted using a low-volume discharge system like a drip tape; however, maintaining a proper number of water outlets is necessary to achieve a uniform moisture content throughout the mat [1]. Water moves up from the saturated mat into the pot through the drainage holes due to the effect of capillary rise, although it is usually recommended to initially add water to the top surface to help start the capillary action.

Capillary wicks are an alternative irrigation system which supply water and nutrients directly from a reservoir into the substrate via an absorptive wick [17] (Figure 4b). Further, the wick maintains a constant moisture level in the growing medium and the rate of water movement is related to the evapotranspiration (ET) loss. Wettable materials such as cotton, nylon, and polyester are widely used as the wick, and there is a significant difference in capillary rise depending on material, width, and weave [18-20]. In the cited research, substrate water content increased with the increase in wick 
width or cross-sectional area. Some studies have modified capillary wick systems by combining capillary wick and trough systems, which in turn have two options: nutrient stagnant wick (NSW) or nutrient flow wick systems (NFW) [18,21,22]. The nutrient solution is allowed to circulate on inclined troughs in NFW systems while the solution is stagnant in NSW systems as described by Son et al. [21].

Negative pressure difference irrigation (NPDI) is a type of capillary irrigation system that uses a porous pipe to deliver water and to control soil moisture potential [15], and represents another approach to achieving a better relationship between plant growth and water uptake (Figure 4a). Multiple studies have assessed the effectiveness of NPDI systems, with [16] and without [23] crops, but its application to field crops is limited. In the NPDI system, negative pressure is created by placing the water source below the porous pipe (Figure 4a), whereas in positive pressure irrigation systems, water has been initially pressurised by a pump or by keeping the source water at a higher level than the water delivery point (e.g., ebb and flow) [23]. In the NPDI system, water will not flow freely into the root zone; rather, the evapotranspiration and capillary suction of the soil draws water up from the reservoir. Accordingly, water movement in this system may be mainly controlled by the water extraction rate of the plant. A comparison of these most commonly practiced subirrigation systems is presented in Table 2.

Table 2. Advantages and disadvantages of commonly practiced subirrigation systems $[1,17,24]$.

\begin{tabular}{|c|c|c|}
\hline Irrigation System & Advantages & Disadvantages \\
\hline $\begin{array}{l}\text { Ebb and flow } \\
\text { Trough systems }\end{array}$ & $\begin{array}{l}\text { - closed systems, where recirculation of } \\
\text { water uses less water compared with } \\
\text { other irrigation systems } \\
\text { require much less fertiliser than top } \\
\text { watering systems, allowing efficient } \\
\text { use of liquid fertiliser } \\
\text { - } \begin{array}{l}\text { recirculation of water } \\
\text { minimises runoff }\end{array} \\
\text { - } \text { no water on foliage reduces } \\
\text { foliar pathogens } \\
\text { - } \quad \text { well suited for producing long lines of } \\
\text { plants to specified standards }\end{array}$ & $\begin{array}{l}\text { - } \\
\text { in the top layer of the growing medium } \\
\text { pH and soluble salt content of water } \\
\text { changes over time } \\
\text { - } \quad \text { potential for spread of soil pathogens } \\
\text { through recirculation of water } \\
\text { - } \text { suitable primarily for } \\
\text { greenhouse application } \\
\text { - } \quad \text { require a pump } \\
\text { - } \quad \text { inst suitable for plants that need more water } \\
\end{array}$ \\
\hline Capillary mat & $\begin{array}{l}\text { - efficient when the light levels and } \\
\text { temperatures are low and humidity } \\
\text { is high } \\
\text { - } \quad \text { well-suited to short crop cycles } \\
\text { water level in containers } \\
\text { remains constant } \\
\text { different plants and pot sizes can be } \\
\text { laid out on the same matting }\end{array}$ & $\begin{array}{l}\text { - } \quad \text { runoff salt levels and nitrate concentrations } \\
\text { tend to be higher than in other systems } \\
\text { liquid fertilisers may produce } \\
\text { algae problems } \\
\text { excess water around pots can cause the } \\
\text { spread of rotting fungi } \\
\text { - } \quad \text { use more water than other bottom watering } \\
\text { systems and require more irrigation events } \\
\text { - } \text { difficult to maintain a consistent } \\
\text { matting wetness } \\
\text { - } \quad \text { require a precise water management system } \\
\text { limited to ornamental plants and herbs }\end{array}$ \\
\hline Capillary wick & 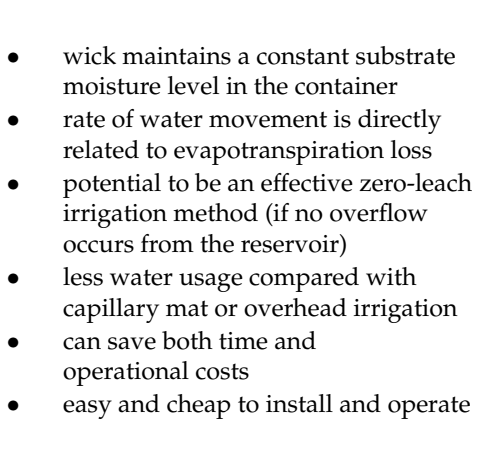 & $\begin{array}{l}\text { primarily used for irrigation of } \\
\text { interior plants } \\
\text { the technology has not been developed for } \\
\text { large-scale commercial plant production } \\
\text { - } \quad \text { low process and plants that need more } \\
\text { water cannot be supported (e.g., tomato } \\
\text { (Solanum lycopersicum)) } \\
\text { most suitable for smaller non-fruiting } \\
\text { plants, e.g., herbs } \\
\text { - } \quad \text { buildup of salt in the growing media } \\
\text { is noted } \\
\text { need a good wick to deliver sufficient water } \\
\text { - } \quad \text { nutrients may settle at the bottom, if the } \\
\text { water is still }\end{array}$ \\
\hline
\end{tabular}




\subsection{Performance and Water Efficiency of Subirrrigation Systems}

\subsubsection{Ebb and Flow Systems}

Most studies have revealed that ebb and flow is one of the most efficient irrigation systems, with additional benefits including high fertiliser efficiency (which reduces costs) and lower environmental impact [25-27]. For example, Santamaria et al. [7] observed that tomato yield was lower in subirrigated trough bench systems, while tomato fruit quality and WUE were higher compared with in a traditional free drainage drip irrigation system. Similar results (i.e., decreased yield and increased WUE) were obtained by Bouchaaba et al. [28] growing green beans (Phaseolus vulgaris). In contrast, Rouphael and Colla $[29,30]$ suggested that subirrigation using the trough technique may provide higher or similar yield and fruit quality when compared with drip irrigation. Cases where lower water use efficiency was observed in ebb and flow systems have usually been attributed to using timers set to a predetermined schedule for long timeframes, without monitoring plant water requirements or substrate moisture levels, resulting in excess plant water uptake [31,32]. Some authors have shown that to overcome this, the use of soil moisture sensors or partial saturation of the substrate may control excess water consumption and allow ebb and flow to achieve a higher WUE and better plant growth $[3,26,32]$. A trough bench subirrigation system with a low-concentration nutrient solution ( $70 \%$ of the standard nutrient solution concentration) was successfully used for closed-cycle cherry tomato cultivation with saline irrigation water, with results similar to those obtained with drip open-cycle cultivation in terms of yield and quality [33].

Precise control of both the water level and timing of the ebb and flow cycle has been shown to be critical to optimising these systems. One study showed that water and fertiliser use efficiency was improved by 20 to $30 \%$ through adopting a regime of holding water on the floor for a shorter duration ( 3 to $5 \mathrm{~min}$ ) compared with longer duration (10 to $15 \mathrm{~min}$ ), without affecting the plant nutrient composition or flower development rate [34]. Ferrarezi et al. [31] observed that different water levels did not affect plant growth in an ebb and flow system, and hence, the application of water according to minimum plant requirements could minimise the nutrient solution pumping costs compared with in systems that apply higher water levels. Meanwhile, Montesano et al. [35] found that precise control of substrate water status through tensiometer-based irrigation may offer the possibility to steer crop response by enhancing different crop performance components, namely, yield and fruit quality, in subirrigated tomato.

\subsubsection{Capillary Mat System}

Dole et al. [25] compared the results of growing ornamental plants (poinsettia (Euphorbia pulcherrima)) using ebb and flow, hand watering, capillary mat, and microtube irrigation. The findings showed that the capillary mat resulted in the lowest plant dry weight and WUE in comparison to the other irrigation treatments. This was attributed to the large amount of water evaporating from the mat. Moreover, the capillary mat had the greatest runoff volume and a comparatively high concentration of nitrates in that runoff. To reduce excess evapotranspiration, advanced capillary mats have been manufactured that have a polyethylene-lined base and a perforated polyethylene or similar cover at the top [36]. Testing has been undertaken on these new mats using seven different nursery plants in a controlled environment during summer and winter seasons [36]. The study found that in comparison to overhead irrigation, capillary mats used about $71 \%$ and $62 \%$ less water to maintain plants in summer and winter, respectively. The authors noted that while overhead sprinklers remain the most cost-effective systems in terms of capital outlay, there is data to suggest that an efficient capillary mat system can provide economic benefits to the extent that their high initial cost can be offset within as little as 12 months compared with hand watering approaches in retail nurseries [36].

Londra et al. [37] studied the variation of water content of several substrates irrigated using drip and subirrigated (capillary mat) systems for growing Begonia and showed that the water content of the substrate was greater in drip-irrigated pots compared with under the capillary mat method. The study 
also investigated oxygen concentration in the soil, finding that oxygen levels decreased with depth through the soil profile in the drip-irrigated substrate, while the concentration was unchanged in subirrigated substrates. However, they argue that other factors, such as EC, would have an effect on plant growth in subirrigation, making a significant plant growth difference between the systems.

Schuch [36] observed that EC levels were higher for plants in capillary mats, but did not reach a level sufficient to induce plant damage. In contrast, Dole et al. [25] reported that capillary mats produced the greatest runoff volume with the highest concentration of nitrogen, did not leach, and conserved more fertiliser compared with overhead irrigation. Fascella and Rouphael [38] have studied the effect of container volume and irrigation systems (drip and capillary mat) on plant growth and WUE of Murraya paniculata plants using a closed system capturing and returning excess nutrient solution back into the tank. Their study showed that capillary mat subirrigation has a greater potential to have higher growth and WUE than drip irrigation, and that suitable manipulation of container volume would further improve the results. The effectiveness of capillary mat systems has been shown to generally decline with an excess application of water to maintain a consistent mat wetness [17]. Capillary mat systems therefore require a precise water management regime to prevent excess water application and subsequent nutrient loss due to runoff and/or evaporation.

\subsubsection{Capillary Wick Irrigation}

Yeager and Henley [2] showed that capillary wick irrigation systems reduced water use an average $86 \%$ and $81 \%$ when compared with overhead and capillary mat irrigation, respectively. In addition, they reported no runoff from the capillary wick reservoir system and an increase in fertiliser use efficiency due to the reduced water application. Additional benefits that were noted were a reduction in human effort (plant demand automatically governs supply of water) and electrical power consumption (no pumping required) [22]. Research has also compared the two types of combined trough-wick systems, indicating there is a higher potential to develop algae in NSW systems than in NFW systems [21]. This may be due to stagnation of the nutrient solution and eutrophication in NSW systems, with nutrients that promote and support the growth of algae (i.e., nitrogen and phosphorous). More importantly, control of irrigation frequency and the level of water in the trough is essential to maintaining the irrigation efficiency of a wick system, and this could be achieved by increasing or decreasing the water level in the reservoir or the cross-sectional area of the wick and substrate material $[18,20]$. However, capillary wick systems tend to be limited to supporting small pot sizes or small non-fruiting crops because the amount of nutrients and water that it can supply is limited. Moreover, capillary wick irrigation systems cannot deliver sufficient nutrients for heavy-feeding crops, such as tomatoes [12]. Some other advantages and disadvantages of the above systems are discussed in Table 2.

\subsubsection{Negative Pressure Difference Irrigation}

A number of researchers have experimented with different NPDI setups and studied their suitability in terms of crop growth and water savings [39-42]. In an NPDI system, the reservoir is placed at a lower level than the root zone and the water moves through a supply tube linking both the reservoir and the plant pot. Nalliah and Ranjan [40] compared the performance of an NPDI system using three negative pressure irrigations $-0.2,0.3$, and $0.6 \mathrm{~m}$ (each representing the height difference between the reservoir water exit level and the entry point in the soil bed)—and a manual irrigation technique. In that study, water consumption by hot pepper (Capsicum annuum) decreased with an increase in negative pressure. However, the plant performance also decreased with the increase in negative pressure. Still, the smallest $(0.2 \mathrm{~m})$ negative pressure system resulted in a $35 \%$ reduction of water use over manual irrigation and had a similar performance in terms of plant growth and yield. This suggests that NPDI could be a useful technique offering precise water delivery and with minimal labour requirements, although it is unclear whether it offers any distinct advantages over capillary wick irrigation. Only five studies were found in this review that investigated the performance of the 
NPDI system. Among these studies, a reduction of water supply due to accumulation of air bubbles under negative pressure is one of the main disadvantages in this system, and as such, careful design of the NPDI system is necessary [42]. A porous ceramic pipe (douche) that is specially made using materials that are water permeable but airtight are used in NPDI systems [43]. The resulting high cost incurred due to the specialised apparatus may explain why these systems are not more widely promoted or studied.

\subsection{Environmental Benefits}

Resource limitation and regulations regarding water use, permissible soil, and surface water pollutant loads in several countries have driven the development of more efficient irrigation and nutrient management systems to minimise environmental impact [2,44]. Several studies have indicated that there is a lower EC in the leachate of capillary-based subirrigated systems compared with overhead irrigation, which could positively contribute to reducing nutrient use, conserving mineral elements in soil, and reducing the overall environmental impact $[17,36,45,46]$. Recirculating systems such as ebb and flow can reduce runoff of water, nutrients, and other agrochemicals, because the nutrient solution is collected and reused within the same system [47]. Accordingly, a potential reduction of fertiliser application could be expected in other subirrigation systems. For example, in subirrigation (trough) systems, growth parameters for potted roses using a $75 \%$ strength nutrient concentration showed equal or better performance to an equivalent treatment irrigated with $100 \%$ strength nutrients (EC of full strength $(100 \%)$ nutrient solution $=1.756 \mathrm{dS} / \mathrm{m}$ ) [48]. In a similar study (with a trough system), it was found that the recommended nutrient concentration could be reduced by up to $50 \%$ for the production of potted gerberas without impacting plant yield or quality [49]. Similar results have been found for tomatoes [33] and green beans [28], where reductions up to 70 and $80 \%$, respectively, of the standard nutrient solution concentration produced even better crop performance than $100 \%$ concentration.

In response to such research, closed systems such as those that use capillary irrigation are gaining popularity as environmentally friendly strategies for managing nutrient requirements in containerised pots compared with open systems, particularly when compared with hand watering methods for irrigation. There are, however, other studies that show limited improvement using subirrigated approaches. Kang et al. [50] studied the impact of different concentrations of water-soluble fertiliser with $\mathrm{N}$ concentrations ranging from 0 to $400 \mathrm{mg} / \mathrm{L}$ for the growth of ornamental pepper when irrigated via ebb and flow or hand irrigation. This study found that fruiting rates were lower at $0 \mathrm{mg} / \mathrm{L} \mathrm{N}$, but there was no significant variation between the irrigation methods using fertiliser concentrations ranging from 100 to $400 \mathrm{mg} / \mathrm{L} \mathrm{N}$. As such, while there was no clear benefit from subirrigation compared to hand watering, there is clearly an opportunity to adopt lower nutrient concentrations without sacrificing plant performance. The effect of fertiliser concentration for the growth of Petunia was studied by Klock-Moore and Broschat [47] using recirculated subirrigation and hand watering methods. Findings indicated that the amount of fertiliser to apply may vary with the type of fertiliser: water soluble or controlled release. Furthermore, recirculating subirrigation systems prevent fertiliser runoff and reduce water and fertiliser use.

\subsection{Salinity in the Substrate}

Salinity of soil is usually measured using EC as an indicator, and is typically expressed in units $\mathrm{dS} / \mathrm{m}$ (or $\mathrm{mS} / \mathrm{cm}$ ). Accumulation of salinity in the upper layer of soil is generally found with subirrigated watering techniques, implying that upward movement of water carried dissolved salt with it. Many studies have demonstrated the accumulation of salinity at the upper layers of soil of subirrigated pots $[17,25,51-53]$. These results are in contrast to the standard expectation of movement of salts downward through the soil in conventional, surface-irrigated systems. This impact is even noted where crops are exposed to natural rainfall. Matysiak and Bielenin [54] observed that accumulation of salts in the top layer of a growing medium was higher for ebb and flow systems compared with overhead irrigation, despite experiencing some leaching due to rain in outdoor-grown plants. 
Several studies also noted that an increase in concentration of the fertiliser for subirrigation tends to increase the level of nutrients and, therefore, EC in the soil substrate $[47,50,54-56]$. Cartmill et al. [57] studied the optimum concentration of $P$ required to grow Catharanthus roseus (L.) "Pacifica White" considering 10 different $\mathrm{P}$ concentrations from 0 to $3 \mathrm{mM}$ at $0.25 \mathrm{mM}$ intervals, keeping $\mathrm{N}$ and $\mathrm{K}$ constant. Results of this study showed that the media $\mathrm{pH}$ decreased with an increase of $\mathrm{P}$ concentration in the nutrient solution in both top watered and recirculated subirrigated systems. However, this study evidenced that irrespective of the $\mathrm{P}$ concentration, subirrigated plants had greater quality and dry mass when compared with surface-irrigated plants.

\subsection{Nutrient Concentration in Foliage}

There have been few studies which have investigated the accumulation of macro $(\mathrm{N}, \mathrm{P}, \mathrm{K}, \mathrm{Ca}$, $\mathrm{Mg}, \mathrm{S}, \mathrm{Na})$ and micro $(\mathrm{Mn}, \mathrm{Fe}, \mathrm{Zn}, \mathrm{Al}, \mathrm{Cu}, \mathrm{B})$ nutrients in the foliage of plants subject to different irrigation techniques. Dole et al. [25] observed that the higher the fertiliser concentration, the higher the N, P, Fe, and Mn concentrations in Poinsettia foliage, regardless of irrigation method (capillary mat, $\mathrm{ebb}$ and flow, or hand watering), but there was no difference in $\mathrm{K}, \mathrm{Ca}, \mathrm{Mg}$, and $\mathrm{Zn}$ concentrations. A study with Catharanthus roseus (L.) plants reported that macro and micro elements such as, N, P, $\mathrm{K}, \mathrm{Mg}, \mathrm{Mn}, \mathrm{Zn}$, and $\mathrm{Cu}$ were generally higher in recirculated subirrigated plant foliage, while $\mathrm{Ca}$, $\mathrm{S}, \mathrm{Fe}, \mathrm{Al}$, and $\mathrm{B}$ were greater in top-irrigated plants [57]. More importantly, Cartmill et al. [57] noted that subirrigated plants had greater quality and dry mass regardless of the P concentration of the nutrient solution. Similar results were observed by $\mathrm{Xu}$ et al. [58], who noted that subirrigation may improve tomato plant physiology, fruit yield, and quality, and produce better resistance to disease when compared with overhead irrigation. Another study reported that there was no difference in $\mathrm{K}$ levels in foliage between a permanently saturated sand bed subirrigated system and overhead sprinkler irrigation [59]. In research by Matysiak and Bielenin [54], the growth, flowering, and nutrient status of Rhododendron yakushimanum was studied using six different nutrient solutions in ebb and flow and a controlled-release fertiliser under overhead irrigation. Their study showed that the nutrient content of leaves increased with an increase of the concentration of the nutrient solution in the ebb and flow system, while the application of controlled-release fertiliser in the overhead-irrigated pots resulted in comparatively low $\mathrm{P}$ and Ca content in leaves.

\subsection{Limitations and Future Research Requirements}

Capillary-driven subirrigation systems are widely practiced in greenhouses, and the literature indicates several advantages compared with surface-irrigated planting systems, considering both economic and environmental aspects. However, each technology also seems to have one or more disadvantages (Table 2). These disadvantages may explain why, although capillary irrigation systems are widely used for growing ornamental and nursery plants, experimentation and use of such systems for growing fruit and vegetable crops-for instance, in small-scale urban agriculture-is comparatively rare. One reason for this may be that ebb and flow, capillary wick, and capillary mats tend to be widely used for growing plants in small containers; the use of the larger pots required for vegetable crops may necessitate high-volume pumps for recirculation of water.

Use of advanced technologies with these systems, for example, the technical components in the system and use of computers for precisely scheduled irrigation, has made them more complicated and expensive [44]. Inability to maintain a consistent matting wetness is one of the main drawbacks in the capillary mat system, which may also lead to inconsistent substrate moisture content or insufficient supply of water to plants. Similarly, water drawn up from the reservoir via a capillary wick may not be sufficient to meet the evapotranspiration rate of larger vegetable plants popular in small-scale agriculture, such as tomatoes. Further, nutrients may stagnate at the bottom of the reservoir in capillary wick systems if the water is kept still for a longer period. Periodic application of water in ebb and flow irrigation systems results in frequent wet and dry cycles within the root zone, while capillary wick 
irrigation provides a continuous water supply which often may result in excess water application for some low-water or drought-tolerant plants.

Fluctuation of $\mathrm{pH}$ and the possibility of spreading disease are other unfavorable situations in recirculating systems [60-62]. Excess salt buildup in the soil may reduce plant growth and yield of produce; hence, proper fertiliser management and control of irrigation efficiency is necessary in order to optimise the technology for high utilisation of these nutrients within the plants. Water and nutrient requirements of plants are known to change periodically during their life cycle. These are complex processes, and empirical relationships tend to be adopted to guide water and nutrient application at different times over a crop cycle. As these relationships have been developed under surface irrigation conditions, there is a need to develop guidance on optimum nutrient application for capillary irrigation systems.

Effectiveness of the subirrigated system is influenced by the capillary properties of the substrate. If substrates used in capillary irrigation systems are too coarse, they will result in poor capillary properties and require more frequent irrigation and may have a negative effect on plant growth, yield, and water use efficiency $[20,63,64]$. However, there has been no standard developed for determining the capillary properties of substrate materials [65].

As fresh water resources become more scarce (especially in cities), there is an increasing need and trend towards development of alternative water sources, including the use of recycled industrial or municipal wastewater, agricultural drainage water, grey water, and brackish water for irrigation. Although many studies can be found applying such water sources in open field experiments, there is limited evidence for their successful use in capillary-based subirrigation systems for growing crops. One study [66] experimented with subirrigation in field lysimeters for growing green peppers and potatoes (Solanum tuberosum), using brackish water with different salinity levels $(1,5,9 \mathrm{dS} / \mathrm{m})$. This study showed that there was no significance difference in yield due to either salinity of subirrigated water or water table depth; this suggests that brackish water may be used successfully, but more supporting evidence and advanced research studies are needed.

\section{Conclusions}

The objective of this study was to investigate commonly used capillary irrigation systems and their performance relative to equivalent best-practice irrigation techniques, and to identify the gaps in the research in terms of their limitations and potential improvements. Performance was compared mainly in terms of water use efficiency and environmental impact. This broad systematic review showed that each irrigation technique comes with distinct advantages, and each can potentially be operated in a way that delivers substantially greater water use efficiency than surface irrigation. This is fundamentally due to the ability of capillary and subirrigation techniques to eliminate the two main water loss pathways in irrigation (evaporation and runoff). However, each technology was also found to come with unique disadvantages, mostly relating to setup costs and complexity of operation, such as the need for precise control of water volumes.

We conclude that despite extensive research on environmental and social benefits for the various traditional capillary-irrigated systems (ebb and flow, capillary mat and wick systems, and negative pressure difference irrigation), no equivalent research has evaluated the water use efficiency and performance of the apparently simpler wicking bed systems. A preliminary assessment of the wicking bed technology in the context of these other approaches suggests that it may represent a unique technology that brings together all of the advantages and none of the disadvantages of the other capillary and subirrigation techniques.

This review of research papers listed in Scopus and Web of Science identified a specific need (and opportunity) to critically assess wicking beds as a potentially more practical alternative to other capillary and subirrigation methods, which—through further optimised design-may ultimately offer a widely scalable solution for highly water- and nutrient-efficient irrigation in urban agriculture. 
Author Contributions: N.P.K.S. conducted the literature review and produced final drafts of the manuscript. Commentary and review of manuscript drafts were conducted by J.D.W. and B.R.M.

Acknowledgments: This research was conducted with the assistance of an Australian Government Endeavour Awards Scholarship. Funding was also provided by the Goyder Institute for Water Research, a partnership between the South Australian Government through the Department of Environment, Water and Natural Resources, CSIRO, Flinders University, the University of Adelaide, and the University of South Australia. This research received no other external funding.

Conflicts of Interest: The authors declare no conflict of interest.

\section{References}

1. Beardsell, D.; Bodman, K.; Cresswell, G.; Mebalds, M.; Nicholas, D.; Rolfe, C.; Yiasoumi, B.; McDonald, J.; Kachenko, A.; Danelon, M. Nursery Industry Water Management Best Management Practice Guidelines; Nursery \& Garden Industry Australia: Epping, NSW, Australia, 2010; p. 104.

2. Yeager, T.; Henley, R. Irrigation and fertilization for minimal environmental impact. In Acta Horticulture; Bertschinger, L., Anderson, J., Eds.; International Society for Horticultural Science: Korbeek-Lo, Belgium, 2004; Volume 638, pp. 233-240.

3. Ferrarezi, R.S.; Weaver, G.M.; van Iersel, M.W.; Testezlaf, R. Subirrigation: Historical overview, challenges, and future prospects. HortTechnology 2015, 25, 262-276.

4. Mallett, R.; Hagen-Zanker, J.; Slater, R.; Duvendack, M. The benefits and challenges of using systematic reviews in international development research. J. Dev. Eff. 2012, 4, 445-455. [CrossRef]

5. Booth, A.; Papaioannou, D.; Sutton, A. Systematic Approaches to a Successful Literature Review; SAGE Publications Ltd.: London, UK, 2012.

6. Bartok, J.W. Ebb and Flow from an Engineer's Viewpoint; University of Connecticut: Storrs, CT, USA, 1989.

7. Santamaria, P.; Campanile, G.; Parente, A.; Elia, A. Subirrigation vs drip-irrigation: Effects on yield and quality of soilless grown cherry tomato. J. Hortic. Sci. Biotechnol. 2003, 78, 290-296. [CrossRef]

8. Austin, C. Wicking Bed-A New Technology for Adapting to Climate Change. Available online: http: / / www.waterright.com.au/ (accessed on 20 October 2015).

9. ModBOX@. Modbox Raised Garden Beds. Available online: http://www.modbox.com.au/wicking-gardenbeds / (accessed on 10 June 2016).

10. Sullivan, C.; Hallaran, T.; Sogorka, G.; Weinkle, K. An evaluation of conventional and subirrigated planters for urban agriculture: Supporting evidence. Renew. Agric. Food Syst. 2015, 30, 55-63. [CrossRef]

11. Semananda, N.P.K.; Ward, J.D.; Myers, B.R. Evaluating the efficiency of wicking bed irrigation systems for small-scale urban agriculture. Horticulturae 2016, 2, 13. [CrossRef]

12. Lane, K.S.; Washburn, D.E. Capillarity tests by capillarimeter and by soil filled tubes. In Highway Research Board Proceedings; Highway Research Board: Washington, DC, USA, 1947; Volume 26, pp. 460-473.

13. Li, X.; Zhang, L.M.; Fredlund, D.G. Wetting front advancing column test for measuring unsaturated hydraulic conductivity. Can. Geotech. J. 2009, 46, 1431-1445. [CrossRef]

14. Hunter, M.N.; Scattini, W.J. The anovapot ${ }^{\circledR}$ and twinpot reduce root escape and save water. In Acta Horticulturae; Snyder, R.L., Ortega-Farias, S., Carlile, W.R., Raviv, M., Nichols, M., Clothier, B., Goodwin, I., Gentile, R., Eds.; International Society for Horticultural Science Korbeek-Lo: Leuven, Belgium, 2016; Volume 1112, pp. 23-30.

15. Hunter, M.N.; Scattini, W.J. The Anovapot(r): Origin, Development and Associated Pot Irrigation Systems; University of Queensland: St Lucia, Australia, 2014.

16. Hunter, M.; Leong, G.; Mitchell, J.; Dieters, M.; Fujinuma, R. Constant water table sub-irrigation of pots allows derivation of root weights (without physical recovery) and repeated measures of in situ growth and water use efficiencies. Plant Soil. 2018, 425, 1-19. [CrossRef]

17. Million, J.; Yeager, T.; Larsen, C. Water use and fertilizer response of azalea using several no-leach irrigation methods. HortTechnology 2007, 17, 21-25.

18. Kang, S.W.; Seo, S.G.; Pak, C.H. Capillary wick width and water level in channel affects water absorption properties of growing media and growth of chrysanthemum and poinsettia cultured in c-channel subirrigation system. Korean J. Hortic. Sci. Technol. 2009, 27, 86-92.

19. Bainbridge, D.A. Wick irrigation for tree establishment. In The Overstory; Agroforestry Net, Inc.: Holualoa, HI, USA, 2012. 
20. Albaho, M.S. Cross sectional area of the root medium affects water uptake of tomato in a closed system. J. Food Agric. Environ. 2006, 4, 175-180.

21. Son, J.E.; Oh, M.M.; Lu, Y.J.; Kim, K.S.; Giacomelli, G.A. Nutrient-flow wick culture system for potted plant production: System characteristics and plant growth. Sci. Hortic. 2006, 107, 392-398. [CrossRef]

22. Ferrarezi, R.S.; Testezlaf, R. Performance of wick irrigation system using self-compensating troughs with substrates for lettuce production. J. Plant Nutr. 2016, 39, 147-161. [CrossRef]

23. Moniruzzaman, S.M.; Fukuhara, T.; Terasaki, H. Experimental study on water balance in a negative pressure difference irrigation system. J. Jpn. Soc. Civ. Eng. 2011, 67, 103-108. [CrossRef]

24. Wesonga, J.M.; Wainaina, C.; Ombwara, F.K.; Masinde, P.W.; Home, P.G. Wick material and media for capillary wick based irrigation system in Kenya. Int. J. Sci. Res. 2014, 3, 613-617.

25. Dole, J.M.; Cole, J.C.; von Broembsen, S.L. Growth of poinsettias, nutrient leaching, and water-use efficiency respond to irrigation methods. HortScience 1994, 29, 858-864.

26. Elmer, W.H.; Gent, M.P.N.; McAvoy, R.J. Partial saturation under ebb and flow irrigation suppresses pythium root rot of ornamentals. Crop Prot. 2012, 33, 29-33. [CrossRef]

27. Morvant, J.K.; Dole, J.M.; Cole, J.C. Fertilizer source and irrigation system affect geranium growth and nitrogen retention. Hortscience 2001, 36, 1022-1026.

28. Bouchaaba, Z.; Santamaria, P.; Choukr-Allah, R.; Lamaddalena, N.; Montesano, F.F. Open-cycle drip vs closed-cycle subirrigation: Effects on growth and yield of greenhouse soilless green bean. Sci. Hortic. 2015, 182, 77-85. [CrossRef]

29. Rouphael, Y.; Colla, G. Growth, yield, fruit quality and nutrient uptake of hydroponically cultivated zucchini squash as affected by irrigation systems and growing seasons. Sci. Hortic. 2005, 105, 177-195. [CrossRef]

30. Rouphael, Y.; Colla, G. The influence of drip irrigation or subirrigation on zucchini squash grown in closed-loop substrate culture with high and low nutrient solution concentrations. HortScience 2009, 44, 306-311.

31. Ferrarezi, R.S.; Van Iersel, M.W.; Testezlaf, R. Plant growth response of subirrigated salvia 'vista red' to increasing water levels at two substrates. Hortic. Bras. 2016, 34, 202-209. [CrossRef]

32. Ferrarezi, R.S.; van Iersel, M.W.; Testezlaf, R. Monitoring and controlling ebb-and flow subirrigation with soil moisture sensors. HortScience 2015, 50, 447-453.

33. Montesano, F.; Parente, A.; Santamaria, P. Closed cycle subirrigation with low concentration nutrient solution can be used for soilless tomato production in saline conditions. Sci. Hortic. 2010, 124, 338-344. [CrossRef]

34. Gent, M.; McAvoy, R. Water and nutrient uptake and use efficiency with partial saturation ebb and flow watering. HortScience 2011, 46, 791-798.

35. Montesano, F.F.; Serio, F.; Mininni, C.; Signore, A.; Parente, A.; Santamaria, P. Tensiometer-based irrigation management of subirrigated soilless tomato: Effects of substrate matric potential control on crop performance. Front. Plant Sci. 2015, 6, 1150. [CrossRef] [PubMed]

36. Schuch, U.K.; Kelly, J.J.; Teegerstrom, T. Capillary mats for maintenance of plants in the retail nursery. HortTechnology 2008, 18, 250-255.

37. Londra, P.A.; Paraskevopoulou, A.T.; Psychoyou, M. Evaluation of water air-balance of various substrates on begonia growth. Hortscience 2012, 47, 1153-1158.

38. Fascella, G.; Rouphael, Y. Growth and water use efficiency of potted murraya paniculata as affected by irrigation system and container size. Eur. J. Hortic. Sci. 2015, 80, 81-86. [CrossRef]

39. Perroux, K.M. Controlled water potential in subirrigated pots. Plant Soil 1979, 52, 385-392. [CrossRef]

40. Nalliah, V.; Ranjan, R.S. Evaluation of a capillary-irrigation system for better yield and quality of hot pepper (capsicum annuum). Appl. Eng. Agric. 2010, 26, 807-816. [CrossRef]

41. Nicola, S.; Pignata, G.; Casale, M.; Lo Turco, P.E.; Gaino, W. Overview of a lab-scale pilot plant for studying baby leaf vegetables grown in soilless culture. Hortic. J. 2016, 85, 97-104. [CrossRef]

42. Iwama, H.; Kubota, T.; Ushiroda, T.; Osozawa, S.; Katou, H. Control of soil water potential using negative pressure water circulation technique. Soil Sci. Plant Nutr. 1991, 37, 7-14. [CrossRef]

43. Shi, X.; Zhou, Q.; Wang, Y.; Cao, C.; Jin, G.; Liu, Y. Research on soil moisture dynamic under negative pressure irrigation. In Advances in Energy, Environment and Materials Science; Wang, Y., Zhao, J., Eds.; CRC Press: Oxon, UK, 2016; pp. 161-164.

44. Roeber, R.U. Environmentally sound plant production by means of soilless cultivation. Comun. Sci. 2010, 1, 1-8. 
45. Nicola, S.; Hoeberechts, J.; Fontana, E. Studies on irrigation systems to grow lettuce (lactuca sativa 1.) transplants. In Acta Horticulturae; Nicola, S., Nowak, J., Vavrina, C.S., Eds.; International Society for Horticultural Science: Korbeek-Lo, Belgium, 2004; Volume 631, pp. 141-148.

46. Pinto, J.R.; Chandler, R.A.; Dumroese, R.K. Growth, nitrogen use efficiency, and leachate comparison of subirrigated and overhead irrigated pale purple coneflower seedlings. Hortscience 2008, 43, 897-901.

47. Klock-Moore, K.A.; Broschat, T.K. Irrigation systems and fertilizer affect petunia growth. HortTechnology 2001, 11, 416-418.

48. Zheng, Y.; Cayanan, D.F.; Dixon, M. Optimum feeding nutrient solution concentration for greenhouse potted miniature rose production in a recirculating subirrigation system. HortScience 2010, 45, 1378-1383.

49. Zheng, Y.; Graham, T.; Richard, S.; Dixon, M. Potted gerbera production in a subirrigation system using low-concentration nutrient solutions. HortScience 2004, 39, 1283-1286.

50. Kang, J.G.; Van Iersel, M.W.; Nemali, K.S. Fertilizer concentration and irrigation method affect growth and fruiting of ornamental pepper. J. Plant Nutr. 2004, 27, 867-884. [CrossRef]

51. Goodwin, P.B.; Murphy, M.; Melville, P.; Yiasoumi, W. Efficiency of water and nutrient use in containerised plants irrigated by overhead, drip or capillary irrigation. Aust. J. Exp. Agric. 2003, 43, 189-194. [CrossRef]

52. Cox, D.A. Growth, nutrient content, and growth medium electrical conductivity of poinsettia irrigated by subirrigation or from overhead. J. Plant Nutr. 2001, 24, 523-533. [CrossRef]

53. Klock-Moore, K.A.; Broschat, T.K. Effect of four growing substrates on growth of ornamental plants in two irrigation systems. HortTechnology 2001, 11, 456-460.

54. Matysiak, B.; Bielenin, M. Effect of nutrient solution composition on growth, flowering, nutrient status and cold hardiness of rhododendron yakushimanum grown on ebb-and-flow benches. Eur. J. Hortic. Sci. 2005, 70, 35-42.

55. Rouphael, Y.; Cardarelli, M.; Rea, E.; Colla, G. The influence of irrigation system and nutrient solution concentration on potted geranium production under various conditions of radiation and temperature. Sci. Hortic. 2008, 118, 328-337. [CrossRef]

56. Guttormsen, G. Accumulation of salts in the sub-irrigation of pot plants. Plant Soil 1969, 31, 425-438. [CrossRef]

57. Cartmill, A.D.; Cartmill, D.L.; Ballweg, D.L.; Valdez-Aguilar, L.A. Optimum phosphorus concentration for growth of catharanthus roseus (1.) g. Don 'pacifica white' in a subirrigation and top watering system. Commun. Soil Sci. Plant Anal. 2016, 47, 52-64. [CrossRef]

58. Xu, H.L.; Qin, F.F.; Xu, Q.C.; Xu, R.Y.; Wang, T.Y.; Wang, R. Applications of xerophytophysiology in plant production: Sub-irrigation improves tomato fruit yield and quality. J. Food Agric. Environ. 2011, 9, $256-263$.

59. Hicklenton, P.R.; Cairns, K.G. Plant water relations and mineral nutrition of containerized nursery plants in relation to irrigation method. Can. J. Plant Sci. 1996, 76, 155-160. [CrossRef]

60. Oh, M.M.; Son, J.E. Phytophthora nicotianae transmission and growth of potted kalanchoe in two recirculating subirrigation systems. Sci. Hortic. 2008, 119, 75-78. [CrossRef]

61. Argo, W.R.; Weesies, B.J.; Bergman, E.M.; Marshal, M.; Biernbaum, J.A. Evaluating rhizon soil solution samplers as a method for extracting nutrient solution and analyzing media for container-grown crops. HortTechnology 1997, 7, 404-408.

62. Strong, S.S.; Behe, B.K.; Deneke, C.F.; Bowen, K.L.; Keever, G.J. Cultivar and spacing effects on transmission of phytophthora parasitica in an ebb-and-flow subirrigation system. Plant Dis. 1997, 81, 89-95. [CrossRef]

63. Van Iersel, M. Root restriction effects on growth and development of salvia (salvia splendens). HortScience 1997, 32, 1186-1190.

64. Heller, H.; Bar-Tal, A.; Assouline, S.; Narkis, K.; Suryano, S.; de la Forge, A.; Barak, M.; Alon, H.; Bruner, M.; Cohen, $\mathrm{S}$. The effects of container geometry on water and heat regimes in soilless culture: Lettuce as a case study. Irrig. Sci. 2015, 33, 53-65. [CrossRef]

65. Caron, J.; Elrick, D.E.; Beeson, R.; Boudreau, J. Defining critical capillary rise properties for growing media in nurseries. Soil Sci. Soc. Am. J. 2005, 69, 794-806. [CrossRef]

66. Patel, R.M.; Prasher, S.O.; Goel, P.K.; Madramootoo, C.A.; Broughton, R.S. Brackish water subirrigation for vegetables. Irrig. Drain. 2003, 52, 121-132. [CrossRef]

(C) 2018 by the authors. Licensee MDPI, Basel, Switzerland. This article is an open access article distributed under the terms and conditions of the Creative Commons Attribution (CC BY) license (http:/ / creativecommons.org/licenses/by/4.0/). 